\title{
Erratum: Why cannot the term development just be dropped altogether? Some reflections on the concept of maturation as alternative to development discourse
}

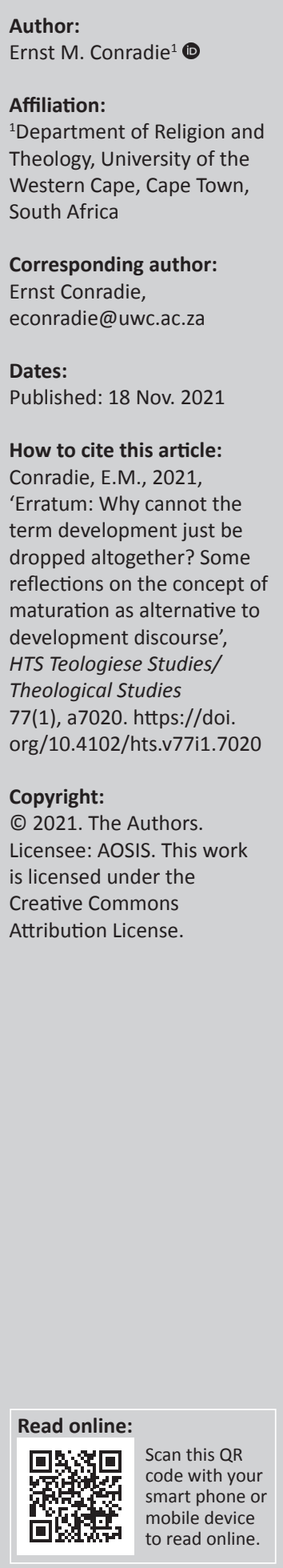

Author:

Affiliation

${ }^{1}$ Department of Religion and Theology, University of the Western Cape, Cape Town, South Africa

Corresponding author: Ernst Conradie,

econradie@uwc.ac.za

Dates:

How to cite this article: Conradie, E.M., 2021, Erratum: Why cannot the dropped altogether? Som reflections on the concept of maturation as alternative to development discourse', HTS Teologiese Studies/ 77(1), a7020. https://doi. ts.v77i1.7020

is licensed under the

reative Commons

Attribution License.
In the version of this article initially published, Conradie, E.M., 2016, 'Why cannot the term development just be dropped altogether? Some reflections on the concept of maturation as alternative to development discourse', HTS Teologiese Studies/Theological Studies 72(4), a3415. https:/ /doi.org/10.4102/hts.v72i4.3415, on page 1, the third paragraph, was set incorrectly.

The sentence is therefore corrected to:

As Aristotle already realised, a metaphor requires the ability to see the similar in the dissimilar, what David Tracy (1981) calls an analogical imagination (see also Conradie 1992).

This correction does not alter the study's findings of significance or overall interpretation of the study results. The publisher apologises for any inconvenience caused. 